\title{
JOB OUTCOMES PADA PROFESI AKUNTAN DI DAERAH ISTIMEWA YOGYAKARTA: MODAL SOSIAL SEBAGAI VARIABEL ANTESEDEN
}

\author{
Arya Samudra Mahardhika, S.E., M.Sc., Ak.
}

\begin{abstract}
ABSTRAK
Salah satu aspek penting dalam meningkatkan hasil outcome kerja karyawan adalah modal sosial (social capital). Modal sosial terdiri dari tiga dimensi, yaitu dimensi struktural, dimensi kognitif, dan dimensi relasional (Leana dan Buren III, 1999; Leana dan Pil, 2006). Penelitian ini bertujuan untuk menginvestigasi pengaruh modal sosial pada job outcomes karyawan (kinerja tugas, kepuasan kerja, dan turnover intention). Responden penelitian adalah profesi akuntan (staf akuntan dan manajemen akuntan) pada perusahaan-perusahaan di Daerah Istimewa Yogyakarta. Jumlah sampel dalam penelitian ini sebanyak 105 responden. Hipotesis dalam penelitian ini diuji dengan menggunakan Structural Equation Modeling-Partial Least Square (SEM-PLS) dengan menggunakan software WarpPLS 3.0. Hasil dari penelitian ini menemukan bahwa dimensi struktural dan dimensi relasional berpengaruh pada job outcomes, yaitu pengaruh positif pada kinerja tugas dan kepuasan kerja, namun berpengaruh negatif pada turnover intention, sedangkan untuk dimensi kognitif menunjukkan pengaruh positif pada kepuasan kerja dan pengaruh negatif pada turnover intention namun tidak menunjukkan pengaruh pada kinerja tugas.
\end{abstract}

Kata kunci: Modal Sosial, Job Outcomes 


\section{PENDAHULUAN}

\section{Latar Belakang}

Modal sosial (social capital) dalam lingkungan kerja merupakan salah satu aspek penting dalam meningkatkan outcome kerja karyawan. Modal sosial terdiri dari tiga dimensi, yaitu dimensi struktural, dimensi kognitif, dan dimensi relasional (Leana dan Buren III, 1999; Leana dan Pil (2006). Penelitian ini bertujuan untuk menginvestigasi pengaruh modal sosial pada job outcomes karyawan (kinerja tugas, kepuasan kerja, dan turnover intention.

Woolcock (2000) menyatakan bahwa penelitian terkait modal sosial telah dilakukan di berbagai bidang ilmu, yakni: pendidikan, kesehatan masyarakat, perkembangan ekonomi dan manajemen, serta manajemen dan organisasi. Kesamaan karakteristik dari sampel dalam penelitian-penelitian tersebut adalah adanya kebutuhan untuk berinteraksi antar satu individu dengan individu lain dalam suatu tempat kerja. Hasil dari penelitianpenelitian tersebut memberikan bukti empiris bahwa modal sosial berpengaruh positif terhadap penciptaan dan pertukaran informasi, kinerja tim yang lebih baik, kinerja organisasional, mengurangi kecenderungan untuk keluar dan meningkatkan keunggulan kompetitif perusahaan. (Krause et al., 2007; Chow dan Chan, 2008; Monnavarian dan Amini, 2009; Roshental, 1997; Bolino et al., 2002), namun demikian, sejauh pengetahuan terbaik peneliti, penelitian di literatur akuntansi yang membahas mengenai modal sosial masih sangat minim.

Mengingat karakteristik akuntan yang membutuhkan interaksi dengan sesama akuntan dalam pekerjaannya, serta bukti-bukti empiris dari penelitian sebelumnya yang memberikan dukungan bahwa modal sosial memiliki pengaruh positif pada peningkatan job outcomes, peneliti termotivasi untuk melakukan penelitian terkait modal sosial di bidang akuntansi, untuk menguji apakah modal sosial dapat digeneralisasikan pada akuntan.

Responden dari penelitian ini adalah profesi akuntan (staf akuntan dan manajemen akuntan) pada perusahaanperusahaan di Daerah Istimewa Yogyakarta. Jumlah sampel dalam penelitian ini sebanyak 105 responden. Hipotesis dalam penelitian ini diuji dengan menggunakan Structural Equation Modeling-Partial Least Square (SEMPLS) dengan menggunakan software WarpPLS 3.0. Alasan penggunaan SEMPLS karena mampu mengestimasi model secara serempak (simultan) sehingga lebih tepat dalam melakukan pengujian (Sholihin dan Ratmono, 2013).

\section{TINJAUAN PUSTAKA}

\section{Modal Sosial}

Istilah modal sosial pada awalnya digunakan untuk mendeskripsikan hubungan sumber daya (resource relationship) yang tertanam dalam hubungan pribadi lintas sektoral yang berguna bagi perkembangan komunitas sosial (social community) seorang individu di dalam perusahaan (Jacobs, 1961; Loury, 1977).

Coleman (1998) dan Putnam (1996) memperluas konsep modal sosial dalam penelitian mereka ke dalam suatu definisi yang lebih luas, yang tidak hanya terkait hubungan sosial tetapi juga norma (norms) dan nilai (values) yang berkaitan dengan hubungan tersebut.

Modal sosial memiliki tiga dimensi, yaitu dimensi struktural, dimensi kognitif, dan dimensi relasional. Menurut Nahapiet dan Ghoshal (1998), dimensi struktural menggambarkan sejauh mana individu dalam organisasi saling berhubungan dan memiliki akses ke intellectual capital individu lainnya 
(dengan siapa dan seberapa sering mereka berbagi informasi satu sama lain). Dimensi kognitif menggambarkan sejauh mana individu-individu dalam suatu organisasi memiliki perspektif yang sama terhadap tujuan organisasi (Nahapiet dan Ghoshal, 1998). Dimensi relasional menggambarkan kepercayaan, timbal balik, dan intensitas emosional antar individu (Nahapiet dan Ghoshal, 1998).

\section{Job Outcomes}

Penelitian ini merujuk job outcomes pada penelitian Fogerty et al. (2000) yang terdiri dari kinerja tugas, kepuasan kerja, dan turnover intention. Istilah kinerja tugas menurut Caillier (2010) digunakan untuk menggambarkan seberapa baik karyawan melaksanakan pekerjaannya.

Campbell et al. mendefinisikan kinerja tugas sebagai kecakapan perilaku kerja terukur yang berada di bawah kendali karyawan dan memberikan kontribusi bagi tujuan perusahaan. Komponen berikutnya dari job outcomes yang digunakan dalam penelitian ini adalah kepuasan kerja, yaitu reaksi emosional dari karyawan terhadap pekerjaan mereka (Happock, 1935). Komponen terakhir dari job outcomes dalam penelitian ini adalah turnover intention, yaitu kecenderungan karyawan untuk berhenti menjadi anggota organisasi (Jaros, 1997).

\section{Hubungan Dimensi Struktural Modal Sosial dan Job Outcomes}

Dimensi struktural modal sosial menggambarkan sejauh mana individu dalam perusahaan saling berhubungan dan memiliki akses ke intellectual capital individu lainnya (Leana dan Pil, 2006). Dengan kata lain, berkaitan dengan pertukaran informasi antar karyawan dalam perusahaan. Bolino et al. (2000) menyatakan bahwa karyawan akan lebih mudah dalam menyelesaikan pekerjaannya ketika mereka memperoleh informasi mengenai pekerjaan dari rekan kerja yang telah berpengalaman dalam pekejaan tersebut. Dengan kata lain, ketika seorang karyawan mengalami kesulitan dalam menyelesaikan pekerjaannya, ia dapat meminta informasi yang dibutuhkan dari rekannya yang lebih berpengalaman untuk menyelesaikan pekerjaannya.

Berdasarkan argumen diatas, peneliti menduga bahwa ketika seorang individu berada dalam lingkungan pekerjaan dimana rekan kerjanya bersedia untuk bertukar informasi mengenai pekerjaan (dimensi struktural modal sosial), akan mempengaruhi job outcomes individu tersebut, yaitu kinerja tugas, kepuasan kerja, dan rendahnya turnover intention. Oleh karena itu, hipotesis kedua dalam penelitian ini adalah:

$\mathrm{H}_{1 \mathrm{a}}$ : Dimensi struktural modal sosial berpengaruh positif terhadap kinerja tugas

$\mathrm{H}_{1 \mathrm{~b}}$ : Dimensi struktural modal sosial berpengaruh positif terhadap kepuasan kerja

$\mathrm{H}_{1 \mathrm{c}}$ : Dimensi struktural modal sosial berpengaruh negatif terhadap turnover intention

\section{Hubungan Dimensi Kognitif Modal Sosial dan Job Outcomes}

Dimensi kedua dari modal sosial adalah dimensi kognitif, yang mana dimensi ini menggambarkan sejauh mana individu dalam perusahaan memiliki perspektif yang sama terhadap tujuan perusahaan (Leana dan Pil, 2006). Ketika karywan memiliki perspektif yang sama terhadap tujuan organisasi, mereka akan lebih mudah untuk mendiskusikan permasalahan kerja, berbagi ide dan pengetahuan, dan saling membantu satu sama lain (Nahapiet dan Ghoshal, 1998). Sejalan dengan itu, Boisot (1995), seperti yang dikutip oleh Bolino et al. (2000), 
menyatakan bahwa kesamaan perspektif akan menciptakan komunikasi yang lebih efektif antar karyawan, sehingga mereka akan dapat memahami dan menafsirkan suatu peristiwa (event) dengan cara yang sama (Boland dan Tenkasi, 1995). Selain itu, Weick (1995), seperti dikutip oleh Bolino et al. (2000), menyatakan bahwa ketika kesamaan perspektif antar karyawan semakin solid, efektifitas dan efisiensi kerja akan lebih sering diperoleh melalui kesadaran bersama dan akan mengurangi perilaku-perilaku yang dapat merugikan organisasi.

Dari argumen diatas, peneliti menduga bahwa ketika karyawan berada dalam lingkungan kerja dimana rekan kerjanya memiliki perspektif atau pandangan yang sama terkait tujuan perusahaan, akan mempengaruhi job outcomes individu tersebut, yaitu kinerja, kepuasan, dan rendahnya keinginan untuk keluar. Oleh karena itu, hipotesis ketiga dalam penelitian ini adalah:

$\mathrm{H}_{2 \mathrm{a}}$ : Dimensi kognitif modal sosial berpengaruh positif terhadap kinerja tugas

$\mathrm{H}_{2 b}$ : Dimensi kognitif modal sosial berpengaruh positif terhadap kepuasan kerja

$\mathrm{H}_{2 \mathrm{c}}$ : Dimensi kognitif modal sosial berpengaruh negatif terhadap turnover intention

\section{Hubungan Dimensi Relasional Modal Sosial dan Job Outcomes}

Dimensi ketiga dari modal sosial adalah dimensi relasional, yang mana hubungan yang terjadi antar karyawan dalam persuahaan ditandai dengan adanya kepercayaan, timbal balik, dan intensitas emosional antar individu (Leana dan Pil, 2006). Berdasarkan Nahapiet dan Ghoshal (1998), karakteristik dari dimensi relasional adalah adanya tingkat kepercayaan yang tinggi, norma-norma bersama, kewajiban yang dirasakan, dan adanya identifikasi bersama. Adanya

kepercayaan antar individu, timbal balik, maupun intensitas emosional antar karyawan akan membentuk suasana kerja yang kondusif. Dengan adanya suasana kerja yang kondusif, karyawan akan merasa nyaman dalam bekerja sehingga ia dapat bekerja dengan lebih baik.

Penelitian Krackhardts (1992), seperti dikutip oleh Bolino et al. (2000) mengindikasikan bahwa hubungan pribadi antar karyawan, sering dihubungkan pada hasil pekerjaan mereka, karena seorang individu merasa lebih nyaman terhadap ketidakpastian, dan lebih terbuka untuk perubahan ketika mereka bekerja dengan rekan-rekan kerja yang mereka sukai. Mullen dan Copper (1994) juga memberikan bukti empiris bahwa hubungan antar karyawan akan meningkatkan kinerja mereka, khususnya ketika pekerjaan mereka membutuhkan kerja sama satu sama lain. Bolino et al. (2000) menyatakan bahwa ketika individu bekerja dengan rekan-rekan kerja yang ia sukai, ia akan lebih fleksibel dan dapat beradaptasi dengan lebih baik pada perubahan lingkungan. Oleh karena itu, peneliti menduga bahwa dimensi relasional modal sosial akan berpengaruh terhadap job outcomes, sehingga hipotesis berikutnya dalam penelitian ini:

$\mathrm{H}_{3 \mathrm{a}}$ : Dimensi relasional modal sosial berpengaruh positif terhadap kinerja tugas

$\mathrm{H}_{3 \mathrm{~b}}$ : Dimensi relasional modal sosial berpengaruh positif terhadap kepuasan kerja

$\mathrm{H}_{3 \mathrm{c}}$ : Dimensi relasional modal sosial berpengaruh negatif terhadap turnover intention 


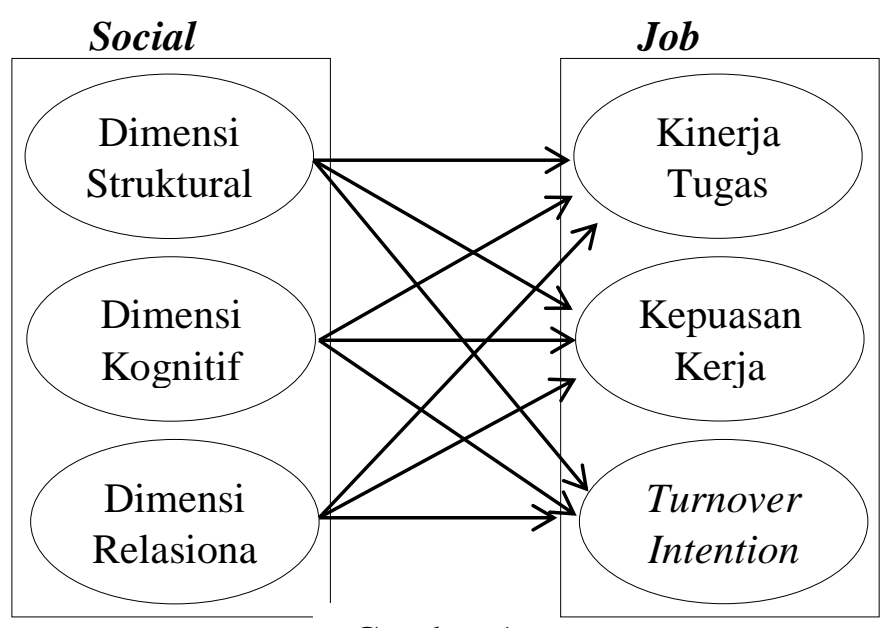

Gambar 1

Model

\section{METODE PENELITIAN}

\section{Sampel dan Data}

Sampel dalam penelitian ini adalah profesi akuntan pada perusahaan di Daerah Istimewa Yogyakarta. Teknik pengambilan sampel dilakukan dengan metode purposive sampling dengan kriteria profesi akuntan yang telah bekerja minimal satu tahun, dengan pertimbangan bahwa mereka telah mengenal lebih baik dan memiliki ikatan emosi dengan sesama rekan akuntan maupun atasan.

Pengumpulan data dalam penelitian ini menggunakan survei langsung. Penyebaran kuisioner dilakukan dengan cara peneliti datang langsung ke perusahaan-perusahaan yang dituju.

Jumlah kuisioner yang disebar adalah 143 kuisioner dan yang kembali 116 kuisioner sehingga jumlah tersebut mrnunjukkan tingkat respon (response rate) sebesar $81,12 \%$. Dari jumlah itu, sebanyak 11 kuisioner tidak dapat digunakan karena data yang tidak lengkap, maupun tidak terpenuhinya kriteria responden yang disyaratkan dalam penelitian ini, sehingga kuisioner yang dapat digunakan dalam penelitian ini sebanyak 105 kuisioner (usable response rate sebesar $73,43 \%$ ).

\section{Pengukuran Variabel}

\section{Modal Sosial}

Dimensi struktural modal sosial diukur dengan menggunakan enam butir pertanyaan yang dikembangkan Leana dan Pil (2006) yang juga digunakan dalam peneltian Pastoriza dan Ariño (2013). Pertanyaan-pertanyaan disusun dengan menggunakan lima (5) skala likert, dengan angka (1) sangat tidak setuju sampai dengan angka (5) sangat setuju.

Dimensi kognitif modal diukur dengan menggunakan enam butir pertanyaan yang dikembangkan Leana dan Pil (2006) yang juga digunakan dalam peneltian Pastoriza dan Ariño (2013). Pertanyaan-pertanyaan disusun dengan menggunakan lima (5) skala likert, dengan angka (1) sangat tidak setuju sampai dengan angka (5) sangat setuju.

Dimensi relasional modal sosial diukur dengan menggunakan enam butir pertanyaan yang dikembangkan Leana dan Pil (2006) yang juga digunakan dalam peneltian Pastoriza dan Ariño (2013). Pertanyaan-pertanyaan disusun dengan menggunakan lima (5) skala likert, dengan angka (1) sangat tidak setuju sampai dengan angka (5) sangat setuju.

\section{Job Outcomes}

Kinerja tugas diukur dengan menggunakan instrumen yang terdiri dari sembilan butir pertanyaan yang dikembangkan oleh Mahoney (1965) yang juga telah digunakan untuk mengukur kinerja dalam penelitian di bidang akuntansi (Lau dan Tan, 1998; Lau dan Roopnarain, 2014). Pertanyaan-pertanyaan disusun dengan menggunakan lima (5) skala likert, dengan angka (1) sangat rendah sampai dengan angka (5) sangat tinggi.

Kepuasan kerja ini diukur dengan menggunakan Minnesota Satisfaction Quisionaire (MSQ) yang dikembangkan oleh Weiss et al. (1967) yang juga 
digunakan oleh Lau dan Sholihin (2005). Alasan penggunaan instrumen ini karena kesuksesannnya dalam memprediksi kepuasan secara keseluruhan (Lau dan Sholihin, 2005) dan telah digunakan pada beberapa penelitian akuntansi manajemen. Pertanyaan-pertanyaan disusun dengan menggunakan lima (5) skala likert, dengan angka (1) tidak puas sampai dengan angka (5) benar-benar puas.

Variabel turnover intention diukur dengan menggunakan instrumen yang terdiri tiga butir pertanyaan yang dikembangkan oleh Mobley (1982). Pertanyaan-pertanyaan disusun dengan menggunakan lima (5) skala likert, dengan angkat (1) sangat tidak setuju sampai dengan angka (5) sangat setuju.

\section{HASIL PENELITIAN}

Hipotesis dalam peneitian ini diuji
dengan menggunakan SEM-PLS. Keterdukungan hipotesis dalam penelitian ini dilihat dari nilai signifikansi ( $P$-values) dan koefisien jalur. Terdapat 9 (sembilan) hipotesis yang diuji dalam penelitian ini. Suatu hipotesis dinyatakan terdukung apabila $p$-value $<0,01$ (signifikan pada tingkat $1 \%$ ), $p$-value $<0,05$ (signifikan pada tingkat 5\%), dan $p$-value < 0,1 (signifikan pada tingkat 10\%). Pada Tabel 1 menyajikan ringkasan hasil pengujian hipotesis penelitian ini.

\section{Hasil Pengujian H1a-H1c: Dimensi Struktural Berpengaruh pada Job outcomes}

Hipotesis 1a dalam penelitian ini menyatakan bahwa dimensi struktural berpengaruh positif pada kinerja tugas. Dapat dilihat pada tabel 1 di atas bahwa pengaruh dimensi struktural pada kinerja tugas memiliki nilai koefisien jalur sebesar 0,296 dan nilai signifikansi $p$-value < 0,001 , dengan kata lain hipotesis 1a dalam penelitian ini terdukung. Hasil penelitian ini mengindikasikan bahwa adanya
Tabel 1

Ringkasan Hasil Pengujian Hipotesis

\begin{tabular}{|c|c|c|c|c|}
\hline & & $\begin{array}{l}\text { Koefisien } \\
\text { Jalur }\end{array}$ & P-values & Keterangan \\
\hline & $\mathbf{D S} \rightarrow$ & & & \\
\hline $\mathbf{H}_{1 \mathbf{a}}$ & $\begin{array}{c}\text { KT } \\
\text { DS } \rightarrow\end{array}$ & 0,296 & $<0,001 * * *$ & Terdukung \\
\hline $\mathbf{H}_{1 \mathrm{~b}}$ & $\begin{array}{l}\text { Kep.K } \\
\text { DS } \rightarrow\end{array}$ & 0,410 & $<0,001 * * *$ & Terdukung \\
\hline $\mathbf{H}_{1 \mathbf{c}}$ & $\begin{array}{c}\text { KK } \\
\mathbf{D K} \rightarrow\end{array}$ & $-0,248$ & $0,030 *$ & $\begin{array}{l}\text { Terdukung } \\
\text { Tidak }\end{array}$ \\
\hline $\mathbf{H}_{2 \mathbf{a}}$ & $\begin{array}{c}\text { KT } \\
\text { DK } \rightarrow\end{array}$ & 0,070 & 0,290 & terdukung \\
\hline $\mathbf{H}_{2 b}$ & $\begin{array}{l}\text { Kep.K } \\
\text { DK } \rightarrow\end{array}$ & 0,212 & $0,033 *$ & Terdukung \\
\hline $\mathbf{H}_{2 \mathrm{c}}$ & $\begin{array}{c}\text { KK } \\
\text { DR } \rightarrow\end{array}$ & $-0,234$ & $0,020 *$ & Terdukung \\
\hline $\mathbf{H}_{3 \mathbf{a}}$ & $\begin{array}{c}\text { KT } \\
\text { DR } \rightarrow\end{array}$ & 0,314 & $0,004 * *$ & Terdukung \\
\hline $\mathbf{H}_{3 \mathbf{b}}$ & $\begin{array}{l}\text { Kep.K } \\
\text { DR } \rightarrow\end{array}$ & 0,236 & $0,009 * *$ & Terdukung \\
\hline $\mathbf{H}_{3 \mathbf{c}}$ & KK & $-0,191$ & $0,037 *$ & Terdukung \\
\hline
\end{tabular}

kebersediaan profesi akuntan untuk saling bertukar informasi dan sumber daya terkait pekerjaan akan mempermudah mereka untuk mencapai kinerja yang lebih baik. Hasil dari penelitian ini sejalan dengan pernyataan Shah (2000) yang menyatakan bahwa pertukaran informasi antar profesi akuntan akan mempengaruhi eksekusi pekerjaan mereka, dan Bolino et al. (2000) yang menyatakan bahwa profesi akuntan akan lebih mudah dalam menyelesaikan pekerjaannya ketika mereka memperoleh informasi mengenai pekerjaan mereka dari rekan kerja yang lebih berpengalaman dalam pekerjaan tersebut.

Hipotesis $1 \mathrm{~b}$ dalam penelitian ini menyatakan bahwa dimensi struktural berpengaruh positif pada kepuasan kerja. Dapat dilihat pada tabel 1 di atas bahwa pengaruh dimensi struktural pada kinerja tugas memiliki nilai koefisien jalur sebesar 0,410 dan nilai signifikansi p-value < 
0,001, dengan kata lain hipotesis $1 \mathrm{~b}$ dalam penelitian ini terdukung. Hasil penelitian ini mengindikasikan bahwa adanya kebersediaan profesi akuntan untuk saling bertukar informasi dan sumber daya terkait pekerjaan akan merasa lebih puas atas pekerjaan mereka. Hasil penelitian ini mendukung hasil penelitian Savari et al. (2013).

Hipotesis 1c dalam penelitian ini menyatakan bahwa dimensi struktural berpengaruh negatif pada turnover intention. Dapat dilihat pada tabel 1 di atas bahwa pengaruh dimensi struktural pada turnover intention memiliki nilai koefisien jalur sebesar -0,248 dan nilai signifikansi $p$-value $<0,05$, dengan kata lain hipotesis 1c dalam penelitian ini terdukung. Hasil penelitian ini mengindikasikan bahwa adanya kebersediaan profesi akuntan untuk saling bertukar informasi dan sumber daya terkait pekerjaan akan mengurangi keinginan mereka untuk keluar dari perusahaan. Hasil penelitian ini mendukung hasil penelitian Krackhardt dan Hanson (1993).

\section{Hasil Pengujian H2a-H2c: Dimensi Kognitif Berpengaruh pada Kepuasan Kerja dan Turnover Intention}

Hipotesis 2a dalam penelitian ini menyatakan bahwa dimensi kognitif berpengaruh positif pada kinerja tugas. Dapat dilihat pada tabel 1 di atas bahwa pengaruh dimensi kognitif pada kinerja tugas memiliki nilai koefisien jalur sebesar 0,070 dan nilai signifikansi $p$-value 0,290, dengan kata lain hipotesis $2 \mathrm{a}$ dalam penelitian ini tidak dapat terdukung. Hasil penelitian ini mengindikasikan bahwa ada tidaknya kesamaan perspektif atau pandangan antar profesi akuntan terkait tujuan perusahaan tidak mempengaruhi kinerja pekerjaan mereka. Hasil penelitian ini mendukung hasil penelitian Tsai dan Ghosal (1998) dan Ariani (2012).

Hipotesis $2 b$ dalam penelitian ini menyatakan bahwa dimensi kognitif berpengaruh positif pada kepuasan kerja. Dapat dilihat pada tabel 1 di atas bahwa pengaruh dimensi kognitif pada kepuasan kerja memiliki nilai koefisien jalur sebesar 0,212 dan nilai signifikansi $p$-value $<0,05$, dengan kata lain hipotesis $2 \mathrm{~b}$ dalam penelitian ini terdukung. Hasil penelitian ini mengindikasikan bahwa adanya kesamaan perspektif atau pandangan antar profesi akuntan terkait tujuan perusahaan akan meningkatkan kepuasan profesi akuntan terhadap pekerjaan mereka. Hasil penelitian ini mendukung hasil penelitian Savari et al. (2013).

Hipotesis 2c dalam penelitian ini menyatakan bahwa dimensi kognitif berpengaruh negatif pada turnover intention. Dapat dilihat pada tabel 1 di atas bahwa pengaruh dimensi kognitif pada turnover intention memiliki nilai koefisien jalur sebesar -0,234 dan nilai signifikansi $p$-value $<0,05$, dengan kata lain hipotesis $2 \mathrm{c}$ dalam penelitian ini terdukung. Hasil penelitian ini mengindikasikan bahwa adanya kesamaan perspektif atau pandangan antar profesi akuntan terkait tujuan perusahaan akan mengurangi keinginan profesi akuntan untuk keluar dari perusahaan. Hasil penelitian ini mendukung hasil penelitian Krackhardt dan Hanson (1993).

\section{Hasil Pengujian H3a-H3c: Dimensi Relasional Berpengaruh Pada Job Outcomes}

Hipotesis $3 \mathrm{a}$ dalam penelitian ini menyatakan bahwa dimensi relasional berpengaruh positif pada kinerja tugas. Dapat dilihat pada tabel 1 di atas bahwa pengaruh dimensi relasional pada kinerja tugas memiliki nilai koefisien jalur sebesar 0,314 dan nilai signifikansi $p$-value $<0,01$, dengan kata lain hipotesis $3 \mathrm{a}$ dalam penelitian ini terdukung. Hasil penelitian ini mengindikasikan bahwa adanya hubungan antar profesi akuntan yang didasarkan atas kepercayaan akan mempermudah mereka untuk mencapai kinerja yang lebih baik. 
Hipotesis $3 b$ dalam penelitian ini menyatakan bahwa dimensi relasional berpengaruh positif pada kepuasan kerja. Dapat dilihat pada tabel 1 di atas bahwa pengaruh dimensi relasional pada kepuasan kerja memiliki nilai koefisien jalur sebesar 0,236 dan nilai signifikansi $p$-value $<0,01$, dengan kata lain hipotesis $3 b$ dalam penelitian ini terdukung. Hasil penelitian ini mengindikasikan bahwa adanya hubungan antar profesi akuntan yang didasarkan atas kepercayaan akan meningkatkan kepuasan mereka terhadap pekerjaan mereka. Hasil penelitian ini mendukung hasil penelitian Savari et al. (2013).

Hipotesis $3 \mathrm{c}$ dalam penelitian ini menyatakan bahwa dimensi relasional berpengaruh negatif pada turnover intention. Dapat dilihat pada tabel 1 di atas bahwa pengaruh dimensi relasional pada turnover intention memiliki nilai koefisien jalur sebesar $-0,191$ dan nilai signifikansi $p$-value $<0,05$, dengan kata lain hipotesis $3 \mathrm{c}$ dalam penelitian ini terdukung. Hasil penelitian ini mengindikasikan bahwa adanya hubungan antar profesi akuntan yang didasarkan atas kepercayaan akan mengurangi keinginan mereka untuk keluar dari perusahaan. Hasil penelitian ini mendukung hasil penelitian Krackhardt dan Hanson (1993).

\section{KESIMPULAN}

Penelitian ini bertujuan untuk menguji pengaruh modal sosial terhadap job outcomes (kinerja tugas, kepuasan kerja, dan turnover intention) pada profesi akuntan di Daerah Istimewa Yogyakarta. Hasil analisis penelitian ini menunjukkan bahwa dimensi struktural dan relasional berpengaruh positif pada kinerja tugas, kepuasan kerja, dan berpengaruh negatif pada turnover intention, sedangkan dimensi kognitif tidak menunjukkan pengaruh pada kinerja tugas, namun berpengaruh pada kepuasan kerja dan turnover intention.

\section{KETERBATASAN DAN SARAN}

Penelitian ini tidak terlepas dari keterbatasan. Keterbatasan pada penelitian ini diantaranya: pertama, sejauh pengetahuan terbaik peneliti, penelitian mengenai modal sosial masih sangat jarang dilakukan di Indonesia, khususnya pada bidang akuntansi, sehingga diperlukan penelitian-penelitian selanjutnya.

Kedua, penelitian dilakukan hanya pada profesi akuntan di Daerah Istimewa Yogyakarta saja, sehingga generalisasi hanya berlaku pada daerah penelitian saja, disarankan bagi penelitian selanjutnya untuk memperluas cakupan wilayah.

\section{DAFTAR PUSTAKA}

Adler, P. S. \& S. Kwon. 2002. Social Capital: Prospect for a New Concept. Academy of Management Review. 27: 1740.

Ariani, D.W. 2012. The Relationship between Social Capital, Organizational Citizenship Behaviors, and Individual Performance: An Empirical Study from Banking Industry in Indonesia. Journal of Management Research. 4: 2.

BPS DI Yogyakarta. 2016. Industri Manufaktur Besar dan Sedang (IBS) dan Industri Mikro Kecil (IMK) Triwulan III Tahun 2016. http://yogyakarta.bps.go.id/Brs/v iew/id/415. Diakses 12 November 2016 pukul 20.07.

Bagozzi, R. \& Y. Yi. 1991. MultitraitMultimethod Matrice in Consumer Reaserch. Journal of Consumer Research. 17: 426439.

Bandura, A. 1986. Social Foundation of Thought and Actions: A Social Cognitive View. Englewood 
Cliffs, New Jersey: Prentice Hall.

Bellou, V. 2008. Exploring Civic Virtue and Turnover intention during Organizational Changes. Journal of Business Research. 61: 778-789.

Boland, R. \& Tenkasi, R. 1995. Perspective Making and Perspective Taking in Communities of Knowing. Organization Science. 6: 350372.

Bolino, M. C., W. H. Turnley, \& J. M. Bloodgood. 2002. Citizenship Behavior and the Creation of Social Capital in Organizations. Academy of Management Review. 505-522.

Brown, M. E. \& L. K. Treviño. 2006. Ethical Leadership: A Review and Future Directions. The Leadership Quarterly. 17: 595616.

Brown, M. E., L. K. Treviño, \& D. A. Harrison. 2005. Ethical Leadership: A Social Learning Perspective for Construct Development and Testing. Organizational Behavior and Human Decision Processes. 97: 117-134.

Chow, W. S. \& L. S. Chan. 2008. Social Capital, Social Trust and Shared Goals in Organizational Knowledge Sharing. Information \& Management. 45 (7): 458-465.

Chughtai, A., M. Byrne, \& B. Flood. 2015. Linking Ethical Leadership to Employee Well-Being: The Role of Trust in Supervisor. Journal of Business Ethics. 128: 653-663.
Coleman, J. S. 1998. Social Capital in the Creation of Human Capital. American Journal of Sociology. 95-120.

Cooper, D.R. \& P.S. Schindler. 2011. Business Research Methods. $11^{\text {th }}$ Edition. Singapore : McGraw Hill.

Fogarty, T. J., J. Singh, G. K. Rhoads, \& R. K. Moore. Antecedents and Consequences of Burnout in Accounting: Beyond the Role Stress Model. Behavioral Research in Accounting. 12: 31-67.

Folger, R. \& Konovsky, M. 1989. Effect of Procedural and Distributive Justice on Reactions to Pay Raise Decision. Academy of Management Journal. 32(1): 115-130.

Ganster, D., H. Hennessey, \& F. Luthans. 1983. Social Desirability Response Effects: Three Alternative Models. Academy of Management Journal. 26: 321331.

Hair, J., T. Hult, \& C. Ringle. 2014 A Primer on Partial Least Squares Structural Equation Modeling (PLS-SEM). Los Angeles: Sage.

Hansen, M. T. 1999. The ResearchTransfer Problem: The Role of Weak Ties in Sharing Knowledge across Organization Subunits. Administrative Science Quarterly. 44 (1): 82112.

Hartono, J. \& W. Abdillah. Konsep dan Aplikasi PLS (Partual Least Square) Untuk Penelitian Empiris. Yogyakarta BPFE.

Hinkin, T. 1995. A Review of Scale Development Practice in the 
Study of Organizations. Journal of Management. 21: 967-988.

Jaros, S. 1997. An Assessment of Meyer and Allen's (1991) ThreeComponent Model of Organizational Commitment and Turnover intentions. Journal of Vocational Behavior. 51(3): 19-37.

Kalkavan, S. \& A. Katrinli. 2014. The Effects of Managerial Coaching Beahvior on the Employees' Perception of Job Satisfaction, Organizational Commitment, and Job Performance: Case Study on Insurance Industry in Turkey. Social and Behavioral Science. 150: 1137-1147.

Konovsy, M. \& Douglas, P. 1994 Citizenship Behavior and Social Exchange. Academy of Management Journal. 37(3): 656-669.

Krackhardt, D. \& J. Hanson. 1993. Informal Networks: The Company behind the Chart. Harvard Business Review. 71(4): 104-111.

Krause, D.R., R. B. Handfield, \& B.B. Tyler. 2007. The Relationship between Supplier Development, Commitment, and Social Capital Accumulation and Performance Improvement. Journal of Operations Management. 25 (2): 528-545.

Lau, C. \& J. Tan. 1998. The Impact of Budget Emphasis, Participation, and Task Difficulty on Managerial Performance: A Cross-Cultural Study of the Financial Services Sector. Management Accounting Research. 9: 163-183.

Lau, C. \& M. Sholihin. 2005. Financial and Nonfinancial Performance
Measures: How do They Affect Job Satisfacton?. The British Accounting Review. 37: 389413.

Lau, C. M., and K. Roopnarain. 2014. The Effects of Nonfinancial and Financial Measures on Employee Motivation to Participate in Target Setting. The British Accounting Review. 46: 228-247.

Leana, C.R. \& F.K. Pil. 2006. Social Capital and Organizational Performance: Evidence from Urban Public Schools. Organizational Science. 17 (3): 353-366.

Leana, C.R. \& H. J. Van Buren. 1999. Organizational Social Capital and Employment Practices. Academy of Management Review. 24 (3): 538-555.

Macintosh, G. \& M. Krush. 2014. Examining the Link between Salesperson Networking Behaviors, Job Satisfaction, and Organizational Commitment: Does Gender Matter?. Journal of Business Research. 67: 26282635.

Mobley, W. 1982. Some Unanswered Questions in Turnover and Withdrawal Research. The Academy of Management Review. 7(1): 111-116.

Monnavarian, A. \& A. Amini. 2009. Do Interactions Within Networks Lead to Knowledge Management?. Business Strategy Series. 10 (3): 139155.

Mullen, B. \& C. Copper. 1994. The Relation between Group Cohesiveness and Performance: An Integration. Psychological Bulletin. 115: 210-277. 
Nahapiet, J. \& S. Ghoshal. 1998. Social Capital, Intellectual Capital, and Organizational Advantage. Academy of Management Review. 23: 242-266.

Neves, P. \& J. Story. 2015. Ethical Leadership and Reputation: Combined Indirect Effects on Organizational Deviance. Journal of Business Ethics. 127: 165-176.

Ohme, M. \& H. Zacher. 2015. Job Performance Ratings: The Relative Importance of Mental Ability, Conscientiousness, and Career Adaptability. Journal of Vocational Behavior. 87:161170.

Oxoby, R. 2009. Understanding Social Inclusion, Social Cohesion, and Social Capital. International Journal of Social Economics. 36 (12): 1133-1152.

Pastoriza, D. \& M. A. Ariño. 2013. Does the Ethical Leadership of Supervisor Generate Internal Modal Sosial?. Journal of Business Ethics. 118:1-12.

Pastoriza, D., M. A. Ariño, \& J. E. Ricart. 2008. Ethical Managerial Behavior as Antecedent of Organizational Social Capital. Journal of Business Ethics. 78(3): 329-341.

Podolny, J. M. 2001. Networks as the Pipes and Prisms of the Market. American Journal of Sociology. 107 (1) 33-60.

Podsakoff, P., S. MacKenzie, J. Lee, \& N. Podsakoff. 2003. Common Method Biases in Behavioral Research: A Critical Review of the Literature and Recommended Remedies. Journal of Applied Psychology. 88(5): 879-903.
Portes, A. 1998. SOCIAL CAPITAL: Its Origins and Applications in Modern Sociology. Annual Review of Sociology. 24: 1-24.

Putnam, R. D. 1996. Bowling Alone: America's Declining Social Capital. Journal of Democracy. 6: 65-78.

Richardson, H., M. Simmering, \& M. Sturman. 2009. A Tale of Three Prespectives Examining Post Hoc Statistical Techniques for Detection and Correction of Common Method Variance. Organizational Research Methods. 12(4): 762-800.

Rosenthal, E. A. 1997. Social Networks and Team Performance. Team Performance Management. 3 (4): 288-294.

Rousseau, D., S. Sitkin, R. Burt, \& C. Camerer. 1998. Not So Different At All: A CrossDicipline View of Trust. Academy of Management Review. 23(3): 405-421.

Savari, M., M. Eslami, \& F. Monavarifard. 2013. The Impact of Social Capital on Agricultural Employees' Job Satisfaction, City of Divandarreh. International Research Journal of Applied and Basic Sciences. 4: 291-295.

Shah, P. 2000. Network Destruction: The Structural Implications of Downsizing. Academy of Management Journal. A3: 101112.

Sholihin, M. \& D. Ratmono. 2013 Analisis SEM-PLS dengan WarpPLS 3.0 Untuk Hubungan Nonlinear dalam Penelitian Sosial dan Bisnis. Yogyakarta: Andy Offset. 
Spagnoli, P., A. Caetano, \& S. Santos. 2012. Satisfaction with Job Aspects: Do Patterns Change Over Time?. Journal of Business Research. 65: 609616.

Sparrowe, R., R. Liden, S. Wayne, \& M. Kramer. 2001. Social Networks and the Performance of Individuals and Groups. The Academy of Management Journal. 44: 316-325.

Strömgen, M., A. Eriksson, D. Bergman, \& L. Dellve. 2015. Social Capital among Healthcare Professionals: A Prospective Study of Its Importance for Job Satisfaction, Work Engagement, and Engagement in Clinical Improvements. International Journal of Nursing Studies. Article in Press.

Sugiarto. 2007. Jumlah Perusahaan di Yogyakarta Meningkat. http://www.suaramerdeka.com/c ybernews/harian/0704/28/dar2.ht m

Taylor, S. \& M. Pattie. 2014. When does Ethical Leadership Affect Workplace Incivility? The Moderating Role of Follower Personality. Business Ethics Quarterly. 24(4): 595-616.

Tipgos, M.A. \& J. P. Trebby. 1987. JobRelated Stresses and Strains in Management Accounting. The Journal of Applied Business Research. 8-14

Tsai, W., \& S. Ghoshal. 1998. Social Capital and Value Creation: The Role of Intrafirm Networks. Academy of Management Journal. 41 (4): 464-476.
Walker, G., B. Kogut, \& W. Shan. 1997. Social Capital, Structural Holes, and the Formation of an Industry Network. Organizational Science. 8: 109125.

Wallin, A., A. Edberg, I. Beck, \& U. Jakobsson. 2013. Psychometric Properties Concerning Four Instruments Measuring Job Satisfaction, Strain, and Stress of Conscience in a Residential Care Context. Archives of Gerontology and Geriastrics. 57: 162-171.

Walumbwa, F. O., D. M. Mayer, P. Wang, H. Wang, K. Workman, \& A. L. Christensen. 2011. Linking Ethical Leadership to Employee Performance: The Roles of Leader-Member Exchange, Self-Efficacy, and Organizational Identification. Organizational Behavior and Human Decision Processes. 115 (2): 204-213.

Woolcock, 2000. The Rise and Routinization of Social Capital, 1988-2008. Annual Review of Political Science. 13: 469-487.

Woolcock, M. \& D. Narayan. 2000. Social Capital: Implications for Development Theory, Research, and Policy. The World Bank Research Observer. 15 (2): 225-249.

Yang, J., Alejandro, \& J. Boles. 2011. The Role of Social Capital and Knowledge Sharing in Selling Center Performance. Journal of Business and Industrial Marketing. 26(3): 152-161. 